\title{
PENGARUH PEMBERIAN DUCKWEED DAN VIRGIN COCONUT OIL (VCO) DALAM PAKAN TERHADAP PERFORMA PRODUKSI DAN DAYA TETAS TELUR AYAM CEMANI
}

\author{
The Effect of Feeding Duckweed and Virgin Coconut Oil (VCO) on Production \\ Performance and Hatchability of Cemani's Eggs
}

\author{
Achmad Rofii, Tyas Rini Saraswati, Enny Yusuf Wachidah Yuniwarti \\ Departemen Biologi, Fakultas Sains dan Matematika, Universitas Diponegoro \\ Email: ahmadrofii290@gmail.com
}

\begin{abstract}
INTISARI
Penelitian ini bertujuan untuk menganalisis pengaruh pemberian duckweed (Lemna minor) dan virgin coconut oil (VCO) dalam pakan terhadap performa produksi, daya tetas, konsumsi pakan, dan bobot badan ayam cemani (Gallus gallus domesticus). Enam belas ekor ayam cemani betina yang dipelihara dari umur 12 minggu hingga periode bertelur pertama dan ditempatkan secara acak dalam kandang berdasarkan Rancangan Acak Lengkap (RAL) dengan 4 perlakuan dan 4 kali ulangan. Perlakuan yang digunakan terdiri dari: pakan standar (T0), pakan standar dengan duckweed 75\% (T1), pakan dengan VCO $10 \mathrm{ml} / \mathrm{kg}$ (T2), pakan standar dengan duckweed 75\% dan VCO $10 \mathrm{ml} / \mathrm{kg}$ (T3). Parameter yang diamati adalah masak kelamin, jumlah telur, fertilitas telur, daya tetas telur, konsumsi pakan, dan bobot badan. Hasil analisis menunjukkan bahwa pemberian duckweed dan VCO dalam pakan berpengaruh $(\mathrm{P}<0,05)$ terhadap masak kelamin, jumlah telur, konsumsi pakan, retensi protein, dan bobot badan, namun tidak berpengaruh $(\mathrm{P}>0,05)$ terhadap fertilitas dan daya tetas telur ayam cemani. Pemberian duckweed $75 \%$ dan VCO $10 \mathrm{ml} / \mathrm{kg}$ dapat digunakan sebagai alternatif untuk perbaikan performa produksi dan asupan nutrisi ayam cemani.
\end{abstract}

Kata kunci: Ayam Cemani, Duckweed, VCO, Daya Tetas, Performa Produksi

\begin{abstract}
The aim of this study was to analyze the effect of using duckweed (Lemna minor) and virgin coconut oil (VCO) in diet on performance, hatchability, feed consumption, and body weight of cemani hen (Gallus gallus domesticus). Sixteen cemani hens were maintained from the age of 12 weeks to the first laying period and housed randomly in cages based on a completely randomized design (CRD) using four treatments and four replications. The treatment consisted: standard feed (TO), standard feed added 75\% duckweed (T1), standard feed added $10 \mathrm{ml} / \mathrm{kg} \mathrm{VCO} \mathrm{(T2),} \mathrm{and}$ standard feed added 75\% duckweed and $10 \mathrm{ml} / \mathrm{kg}$ VCO (T3). The parameters were evaluated: age of maturity, egg number, fertility, hatchability, feed consumption, protein retention, and body weight. The results showed that feeding of duckweed and VCO had significant $(P<0.05)$ effects on age of maturity, egg number, feed consumption, protein retention, and body weight, but there were no significant $(P>0.05)$ effects on fertility, and hatchability of cemani's hen. The feeding of duckweed $75 \%$ and VCO $10 \mathrm{ml} / \mathrm{kg}$ can be used as an alternative to improve performance and nutritional intake of cemani's hen.
\end{abstract}

Keywords: Cemani, Duckweed, VCO, Hatchability, Performance 


\section{PENDAHULUAN}

Ayam Cemani adalah salah satu jenis ayam kedu yang merupakan ayam lokal Indonesia khususnya di daerah Kedu Kabupaten Temanggung yang memiliki ciri warna tubuh hitam dominan (Ismoyowati, et al., 2012; Rofii et al., 2018). Ayam jenis ini memiliki nilai ekonomi yang lebih tinggi dibandingkan dengan Ayam Kedu lain, namun kendala yang dihadapi dalam beternak ayam cemani adalah penyakit, tingkat mortalitas Day Old Chick (DOC) lebih tinggi dan daya tetas yang rendah dibandingkan ayam lokal lain (Tjahjadi, 2010). Pembibitan secara selektif diperlukan untuk memenuhi permintaan pasar dan sebagai bibit pengganti. Upaya untuk mememenuhi hal tersebut dipengaruhi oleh 2 faktor yaitu performa produksi dan daya tetas telur dari Ayam Cemani.

Faktor yang mempengaruhi performa produksi dan daya tetas telur antara lain asupan nutrisi untuk induk, umur induk, kesehatan induk, kualitas telur, serta lama penyimpanan telur yang akan ditetaskan (King'ori, 2011). Nutrisi pakan yang menunjang dalam produktivitas dan daya tetas telur ayam adalah protein, karbohidrat, lemak, mineral, vitamin dan air (Teteh et al., 2010). Nutrisi dalam pakan khususnya protein dan lemak diperlukan dalam proses vitelogenesis didalam hati dan juga dalam peningkatan bobot badan (Suryadi et al., 2018; Torrico et al., 2014). Bahan campuran yang dapat digunakan untuk perbaikan komposisi pakan diantaranya adalah duckweed (Lemna minor) dan Virgin Coconut Oil (VCO). Duckweed (Lemna minor) adalah salah satu tumbuhan akuatik yang memiliki kandungan protein hingga $43 \%$ dari berat kering dan dapat digunakan sebagai bahan campuran pakan ternak (Yilmaz et al., 2004). Duckweed memiliki kandungan protein lisin, methionin, dan threonin lebih tinggi dibandingkan dengan tumbuhan hijau lain (Mwale dan Gwaze, 2013) dan dapat diberikan ke ternak tanpa menimbulkan efek yang merugikan (Akter et al., 2011). Sedangkan VCO merupakan bahan potensial dalam meningkatkan kekebalan tubuh dimana VCO mengandung Medium Chain Fatty Acids (MCFA) yang berpotensi dalam meningkatkan daya tahan tubuh (Yuniwarti et al., 2013) dan mengontrol aktifitas hormon estradiol dalam tubuh sehingga diharapkan mampu memperbaiki kualitas dan daya tetas telur ayam (Kim et al., 2007; Hrabia, 2015).

Penelitian ini dilakukan untuk menganalisis apakah penggunaan duckweed dan VCO sebagai campuran pakan dapat mempengaruhi performa produksi, daya tetas dan bobot badan ayam cemani.

\section{MATERI DAN METODE}

\section{Pembuatan Pakan dan Pemeliharaan}

Pakan yang digunakan adalah pakan standar yaitu campuran bekatul, jagung dan konsentrat (BC-12) dengan perbandingan 3:4:3, duckweed, dan VCO. Proses pembuatan bahan campuran duckweed dilakukan dengan cara duckweed terlebih dulu dicuci dengan air dan dikeringkan, kemudian dianginkan selama 1 malam, lalu dioven pada suhu $80^{\circ} \mathrm{C}$ selama 12 jam. Duckweed diambil dari area persawahan Desa Ngablak Kecamatan Genuk Kota Semarang. Hasil analisis proksimat pakan standar dan duckweed disajikan pada Tabel 1.

Ayam Cemani yang digunakan dalam penelitian ini merupakan ayam hasil ternak di peternakan "Makukuhan" Kedu , Kabupaten Temanggung, Jawa Tengah. Telur tetas yang diamati adalah hasil peneluran pertama. Ayam Cemani betina dipelihara di dalam 4 kandang berukuran (p x l x t) $200 \mathrm{~cm}$ x $350 \mathrm{~cm}$ x $200 \mathrm{~cm}$ masing-masing berisi 4 ekor ayam betina dan 1 ekor ayam jantan. Pemberian pakan dilakukan pada jam 10.00 WIB dan 14.30 WIB dengan pemberian air minum secara ad libitum. Pengamatan dimulai sejak ayam berumur 12 minggu hingga periode bertelur pertama. 
Tabel 1. Hasil analisis proksimat pakan standar dan duckweed

\begin{tabular}{ccccccr}
\hline \multirow{2}{*}{ Sample } & \multirow{2}{*}{ Ulangan } & \multicolumn{5}{c}{ Kandungan Nutrisi } \\
\cline { 3 - 7 } & & Protein (\%) & Lemak (\%) & Air (\%) & Abu (\%) & EM (kal/g) \\
\hline \multirow{2}{*}{ Pakan Standar } & 1 & 11,1 & 5,43 & 11,39 & 7,37 & 3567,73 \\
\multirow{2}{*}{ Duckweed } & 2 & 12,18 & 5,54 & 12,42 & 8,41 & 3628,42 \\
& 1 & 18,66 & 6,59 & 4,11 & 16,89 & 3486,21 \\
& 2 & 18,99 & 6,43 & 4,04 & 16,67 & 3537,46 \\
\hline
\end{tabular}

\section{Koleksi Data}

Fertilitas dilihat dengan cara candling pada hari ke-7 periode inkubasi (Osman et al., 2010). Bobot badan diukur pada saat ayam bertelur pertama hingga hari ke-12. Produksi telur dihitung setiap hari selama masa bertelur pertama.

Nilai rata-rata Fertilitas dan daya tetas dihitung menggunakan rumus (Osman et al., 2010):

$\begin{gathered}\text { Fertilitas } \\ (\%)\end{gathered}=\frac{\Sigma \text { Telur Fertil }}{\Sigma \text { Telur Produksi }} \times 100 \%$

$\underset{(\%)}{\text { Daya tetas }}=\frac{\Sigma \text { Telur Menetas }}{\Sigma \text { Telur Fertil }} \times 100 \%$

Retensi protein dihitung dengan rumus (Fitasari et al., 2016):

$\Sigma$ Protein Konsumsi $-\Sigma$ Protein ekskreta $\Sigma$ Protein Konsumsi

\section{Analisis Data}

Rancangan percobaan yang digunakan adalah rancangan acak lengkap (RAL) dengan 4 perlakuan dan 4 ulangan. Analisis data menggunakan ANOVA dan apabila terdapat perbedaan secara nyata akan dilakukan uji DMRT (Duncan's Multiple Range Test) dengan probabilitas $5 \%$.

Perlakuan:

$\mathrm{T} 0=$ pakan standar

$\mathrm{T} 1=$ pakan standar + duckweed $75 \%$

$\mathrm{T} 2$ = pakan standar + VCO $10 \mathrm{ml} / \mathrm{kg}$

$\mathrm{T} 3$ = pakan standar + duckweed $75 \%$ dan VCO $10 \mathrm{ml} / \mathrm{kg}$

Parameter yang diamati dalam penelitian ini adalah masak kelamin, jumlah telur, jumlah telur yang fertil, daya tetas, konsumsi pakan, retensi protein, dan bobot badan.

\section{HASIL DAN PEMBAHASAN}

\section{Masak Kelamin, Jumlah Telur, Fertilitas dan Daya Tetas Daya Tetas}

Hasil analisis daya tetas telur ayam cemani setelah pemberian duckweed dan VCO dalam pakan yang meliputi masak kelamin, jumlah telur, fertilitas, dan daya tetas disajikan pada Tabel 2. Hasil analisis dengan ANOVA diketahui bahwa pemberian duckweed dan VCO dalam pakan berpengaruh nyata $(\mathrm{P}<0,05)$ terhadap masak kelamin dari ayam cemani. Perbedaan masak kelamin disebabkan aktifitas asam lemak dari pakan didalam tubuh ayam cemani.

Penambahan VCO ke dalam pakan ayam memberikan sumber kolesterol tambahan dari pakan. Kandungan asam laurat yang tinggi dalam VCO akan mengalami metabolisme menjadi asetil koenzim A. Asetil koenzim A akan digunakan sebagai sumber pembentukan kolesterol. Kolesterol yang berasal dari asam lemak tidak jenuh digunakan sebagai prekursor steroid yang disimpan dalam jumlah yang banyak di sel-sel theka interna. Sintesis hormon estrogen terjadi di dalam sel-sel theka interna dan selsel granulosa ovarium. Hormon esterogen akan dijaga dalam keadaan homeostasis dengan melibatkan follicle stimulating hormone (FSH) dan luteinizing hormone (LH). Kelebihan kolesterol akan diangkut dalam bentuk high density lipoprotein (HDL) kemudian ditransportasikan kembali ke hati untuk proses vitelogenesis (Hrabia, 2015). 
Tabel 2. Rataan masak kelamin, jumlah telur, fertilitas, dan daya tetas telur ayam cemani

\begin{tabular}{lllll}
\hline \multirow{2}{*}{ Parameter } & \multicolumn{4}{c}{ Rata-rata \pm St. Dev } \\
\cline { 2 - 5 } & \multicolumn{1}{c}{ T0 } & \multicolumn{1}{c}{ T1 } & \multicolumn{1}{c}{ T2 } & \multicolumn{1}{c}{ T3 } \\
\hline Masak kelamin (hari) & $195.00^{\mathrm{a}} \pm 0.82$ & $194.75^{\mathrm{a}} \pm 0.50$ & $194.00^{\mathrm{ab}} \pm 0.82$ & $193.50^{\mathrm{b}} \pm 0.58$ \\
Jumlah telur (butir) & $10.00^{\mathrm{c}} \pm 0.82$ & $12.75^{\mathrm{ab}} \pm 0.50$ & $11.75^{\mathrm{b}} \pm 0.50$ & $13.75^{\mathrm{a}} \pm 0.96$ \\
Fertilitas (\%) & $78.00 \pm 8.45$ & $80.50 \pm 4.12$ & $87.25 \pm 5.00$ & $80.00 \pm 4.24$ \\
Daya tetas (\%) & $71.25 \pm 11.79$ & $75.75 \pm 9.60$ & $73.50 \pm 3.32$ & $72.50 \pm 2.89$ \\
\hline $\begin{array}{l}\text { a,b,c Superskrip huruf yang berbeda pada baris yang sama menunjukkan berbeda nyata }(\mathrm{P}<0,05) \\
\text { ns Tidak berbeda nyata }(\mathrm{P}>0,05)\end{array}$
\end{tabular}

Perbedaan jumlah telur yang dihasilkan pada masing-masing kelompok diduga akibat perbedaan campuran pakan yang diberikan. Kandungan protein pada T1 dan T3 berbeda dengan T0 dan T1. Sedangkan asam lemak pada T2 dan T3 berbeda dengan T1 dan T3. Protein berperan aktif dalam vitelogenesis di hati sedangkan asam lemak sebagai prekursor hormon steroid. VCO mengandung asam lemak berupa asam linoleat yang berperan dalam memacu pembentukan hormon estrogen (Kim et al., 2007). Duckweed mengandung protein yang berperan dalam sintesis vitelogenin di hati, kemudian disekresikan ke aliran darah dan dibawa menuju folikel ovarium untuk pertumbuhan hirarki folikel. Pertumbuhan hirarki folikel dapat mempercepat pematangan folikel, yang dibuktikan dengan memperpendek waktu siklus ovulasi (Saraswati dan Tana, 2016). Perbaikan komposisi protein dalam pakan mengakibatkan konsumsi protein meningkat, hal ini mengakibatkan terjadi peningkatan pertumbuhan ovarium dan folikel (Anderson et al., 2011).

Hasil analisis fertilitas dan daya tetas tidak menunjukkan perbedaan yang nyata $(\mathrm{P}>0,05)$. Hal tersebut diduga karena protein yang diberikan belum mencukupi untuk meningkatkan fertilitas dan daya tetas telur. Kandungan protein dalam pakan didistribusikan sama di dalam telur sehingga tidak berpengaruh terhadap daya tetas. Selain itu, faktor gen dan lingkungan juga dapat mempengaruhi fertilitas dan daya tetas. Fertilitas dan daya tetas merupakan parameter utama dalam performa produksi, dimana hal tersebut dipengaruhi oleh gen dan lingkungan (King'ori, 2011). Tingkat fertilitas dan daya tetas setiap jenis ayam berbeda (Osman et al., 2010). Kematian embrio terjadi pada telur karena komposisi asam lemak pada kuning telur memiliki efek samping yang merugikan pada kelangsungan hidup embrio (Aydin et al., 2001; King'ori, 2011).

\section{Konsumsi Pakan, Retensi Protein, dan Bobot Badan}

Hasil analisis konsumsi pakan, retensi protein, dan bobot badan ayam cemani setelah pemberian duckweed dan VCO dalam pakan disajikan pada Tabel 3.

Perbedaan konsumsi pakan disebabkan oleh asupan protein dan energi metabolis oleh ayam cemani. Protein dan energi dibutuhkan oleh ayam untuk kebutuhan hidup pokok dan kebutuhan untuk pertumbuhan. Kebutuhan protein dan energi metabolis ayam pada umur 10 sampai 20 minggu sebesar 16 sampai $18 \%$ dan energi metabolismenya (ME) sebesar $2.869 \mathrm{kkal} / \mathrm{kg}$ (Isika, et al., 2006; Teteh et al., 2010). Hasil analisis proksimat pakan standar dan duckweed diketahui bahwa pakan yang diberikan pada ayam cemani memiliki kandungan protein berturut-turut sebesar $11 \%$ dan $18 \%$, sedangkan kandungan energi metabolismenya sebesar 3.598,1 kkal/kg dan $3.511,8 \mathrm{kkal} / \mathrm{kg}$.

Pakan dengan campuran duckweed memiliki kandungan energi metabolis yang tinggi. Pakan dengan kandungan energi metabolis tinggi mengakibatkan konsumsi pakan semakin sedikit dikonsumsi demikian sebaliknya jika energi metabolis pakan rendah 
akan dikonsumsi semakin banyak untuk memenuhi kebutuhannya. Konsumsi protein yang tinggi juga dapat mempengaruhi asupan protein ke dalam daging dan asam-asam amino tercukupi di dalam tubuhnya sehingga metabolisme sel-sel dalam tubuh berlangsung secara normal (Anderson et al., 2011). Pemberian campuran VCO dalam pakan juga mampu menurunkan jumlah konsumsi pakan karena VCO mengandung asam lemak yang dapat meningkatkan energi metabolisme tubuh. Konsumsi pakan dipengaruhi oleh kandungan energi pada pakan, sehingga semakin tinggi energi metabolik ransum menyebabkan penurunan konsumsi ransum (Isika et al., 2006; Husmaini et al., 2013).

Tabel 3. Rataan konsumsi pakan, retensi protein, dan bobot badan ayam cemani

\begin{tabular}{lcccc}
\hline \multirow{2}{*}{\multicolumn{1}{c}{ Parameters }} & \multicolumn{4}{c}{ Rata-rata \pm St. Dev } \\
\cline { 2 - 5 } & T0 & T1 & T2 & T3 \\
\hline Konsumsi pakan (g) & $93.75^{\mathrm{a}} \pm 0.45$ & $88.75^{\mathrm{b}} \pm 0.69$ & $85.00^{\mathrm{c}} \pm 0.84$ & $88.75^{\mathrm{b}} \pm 0.93$ \\
Retensi protein (\%) & $56.00^{\mathrm{b}} \pm 0.82$ & $69.75^{\mathrm{a}} \pm 0.50$ & $55.50^{\mathrm{b}} \pm 0.58$ & $70.25^{\mathrm{a}} \pm 0.50$ \\
Bobot badan (g) & $1462.0^{\mathrm{b}} \pm 47.9$ & $1568.8^{\mathrm{a}} \pm 68.8$ & $1481.2^{\mathrm{b}} \pm 37.5$ & $1568.8^{\mathrm{a}} \pm 42.7$ \\
\hline a,b,c Superskrip huruf yang berbeda pada baris yang sama menunjukkan berbeda nyata $(\mathrm{P}<0,05)$
\end{tabular}

Tingginya konsumsi pakan berkorelasi dengan pertambahan bobot badan. Konsumsi protein yang tinggi akan diikuti dengan retensi protein yang tinggi serta akan terjadi penambahan bobot badan bila energi dalam ransum cukup, tetapi bila energi ransum rendah tidak selalu diikuti dengan peningkatan bobot badan. Protein yang terkandung dalam duckweed akan dipecah menjadi asam amino dan diserap oleh tubuh. Asam amino hasil dari pencernaan selanjutnya akan ditransportasikan oleh plasma darah menuju ke sel atau jaringan. Asam amino di dalam sel atau jaringan akan digunakan untuk pertumbuhan, perkembangan, regenerasi sel dan mensintesis enzim serta hormon (Mwale dan Gwaze, 2013). Energi dan protein merupakan nutrisi utama yang mempengaruhi pertumbuhan ayam. Penurunan konsumsi nutrien ini akan menyebabkan penurunan pertumbuhan ayam (Suthama, 2005).

\section{KESIMPULAN}

Pemberian duckweed 75\% dan VCO 10 $\mathrm{ml} / \mathrm{kg}$ dapat digunakan sebagai alternatif untuk perbaikan performa produksi dan asupan nutrisi ayam cemani.

\section{UCAPAN TERIMAKASIH}

Penulis mengucapkan terimakasih yang sebesar-besarnya kepada "KTT Makukuhan Mandiri" Kabupaten Temanggung, Jawa Tengah dan Keluarga Besar Laboratorium Biologi Struktur dan Fungsi Hewan, Departemen Biologi, Fakultas Sains dan Matematika, Universitas Diponegoro atas partisipasi serta bantuannya selama penelitian.

\section{DAFTAR PUSTAKA}

Akter, M., S.D. Chowdhury, Y. Akter, and M.A. Khatun. 2011. Effect of duckweed (Lemna minor) meal in the diet of laying hen and their performance. Bangladesh Research Publications Journal. 5(3): 252-261.

Anderson, K.E., Z. Lowman, A.M. Stomp, and J. Chang. 2011. Duckweed as a feed ingredient in laying hen diets and its effect on egg production and composition. International Journal of Poultry Science. 10(1): 4-7.

Aydin, R., M.W. Pariza, and M.E. Cook. 2001. Olive oil prevents the adverse affects of dietary conjugated linolieic acid on chick hatchability and egg quality. Journal of nutrition. 131(3): 800-806. 
Fitasari, E., K. Reo, dan N. Niswi. 2016. Penggunaan kadar protein berbeda pada ayam kampung terhadappenampilan produksi dan kecernaan protein. Jurnal Ilmu-Ilmu Peternakan. 26(2): 73-83.

Hrabia, A. 2015. Growth hormone production and role in the reproductive system of female chicken. General and Comparative Endocrinology. 220: 112118.

Husmaini, M.H. Abbas, E. Purwati, and E. Erwan. 2013. Effect of the levels of the virgin coconut oil processing waste (blondo) on productive performance and egg quality of laying hens. International Journal of Poultry Science. 12(3): 164-168.

Isika, M.A., B.I. Okon, E.A. Agiang, and J.A. Oluyemi. 2006. Dietary energy and crude protein requirement for chicks of nigerian local fowl and crossbreds. International Journal of Poultry Science. 5(3): 271-274.

Ismoyowati, Sukardi, and A. Susanto. 2012. Genetic diversity of kedu chicken based on phenotypic characteristics and microsatellite loci. International Journal of Poultry Science. 11(9): 605-610.

Kim, J.H., J. Hwangbo, N.J. Choi, H.G.Park, D.H.Yoon, E.W. Park, S.H. Lee, B.H. Park, and Y.J. Kim. 2007. Effect of dietary supplementation with conjugated linoleic acid, with oleic, linoleic, or linolenic acid, on egg quality characteristics and fat accumulation in the egg yolk. Poultry Science. 86(6): 1180-1186.

King'ori, A.M. 2011. Review of the factors that influence egg fertility and hatchabilty in poultry. International Journal of Poultry Science. 10(6): 483-492.

Mwale, M., and F.R. Gwaze. 2013. Characteristics of duckweed and its potential as feed source for chickens reared for meat production: a review. Scientific Research and Essays. 8(18): 689-697.

Osman, A.M.R., H.M.A. Wahed, and M.S. Ragab. 2010. Effects of supplementing laying hens diet with organic selenium on egg production, egg quality, fertility and hatchability. Egyptian Poultry Science Journal. 30(3): 893-915.
Rofii, A., T.R. Saraswati, dan E.Y.W. Yuniwarti. 2018.Phenotypic characteristics of Indonesian native chickens. Journal of Animal Behaviour and Biometeorology. 6(3): 56-61.

Saraswati, T.R., and S. Tana. 2016. Effect of turmeric powder supplementation to the age of sexual maturity, physical, and chemical quality of the first japanese quail's (Coturnix japonica) egg. Biosaintifika. 8(1): 18-24.

Suryadi, U., B. Prasetyo, dan J.B. Santoso. 2018. Penambahan kromium organik pada pakan yang dibatasi terhadap performa produksi puyuh (Coturnix coturnix japonica) pada fase pre-layer. Jurnal Ilmu Peternakan Terapan. 2(1): 32-40.

Suthama, N. 2005. Kajian aspek "protein turnover" tubuh pada ayam kedu periode pertumbuhan. Media Peternakan. 29(2): 47-53.

Teteh, A., K. Tona, K. Aklikokou, M. Gbeassor, J. Buyse, and E. Decuypere. 2010. Effects of low-protein or high energy levels diets on layer-type chick juvenile performance. International Journal of Poultry Science. 9(12): 1156-1160.

Tjahjadi, H. 2010. Potensi usaha peternakan ayam cemani (studi kasus peternakan ayam cemani di Temanggung). Tesis. Sekolah Pascasarjana. Institut Pertanian Bogor. Bogor.

Torrico, D.D., W. Wardy, K.M. Carabante, K.D Pujols, Z. Xu, H.K. No, and W. Prinyawiwatkul. 2014. Quality of eggs coated with oil chitosan emulsion: combined effects of emulsifier types, initial albumen quality, and storage. Food Science and Technology. 57(1): 35-41.

Yllmaz, E., I. Akyurt, and G. Günal. 2004. Use of duckweed, Lemna minor, as a protein feedstuff in practical diets for common carp, cyprinus carpio, fry. Turkish Journal of Fisheries and Aquatic Sciences. 4: 105-109.

Yuniwarti, E.Y.W., A. Asmara, W.T. Artama, and C.R. Tabbu. 2013. Virgin coconut oil increases the phagocytosis activity of macrophage of broiler chicken following avian influenza vaccination. Jurnal Veteriner. 14(2): 190-196. 